\title{
DAMPAK PANDEMI COVID-19 TERHADAP BISNIS DAN EKSISTENSI PLATFORM ONLINE
}

\section{(THE IMPACT OF COVID-19 PANDEMIC ON BUSINESS AND ONLINE PLATFORM EXISTANCE)}

\author{
Oleh: \\ Taufik'), Eka Avianti Ayuningtyas' ${ }^{2)}$ \\ Sekolah Tinggi Ilmu Ekonomi IPWI Jakarta1,2) \\ alwitaufik@yahoo.com ${ }^{11}$; eka.avianti@gmail.com $\left.{ }^{2}\right)$
}

Review: 19 Apr 2020

Accept: 25 Apr 2020

Publish: 30 Apr 2020

\begin{abstract}
This study aims to identify and analyze the impact of the Covid-19 pandemic on online platformbased business activities in Jakarta. The research method used is descriptive qualitative method, using secondary data sources from research results, references and online news related to research. The study period was conducted from January to mid-April 2020. Data collection techniques using documentation techniques. It was found that the impact of the Covid-19 pandemic, clustered in 3 business activity states, first the business survived or stable, the second business declined and the third business flourished. Stable business through adjusting interaction models using online application platforms is education, especially for food / beverage delivery and basic needs, and health products. The declining business is based on visits or the presence of consumers in places heavily affected by the Covid-19 pandemic, such as public transportation, tourism, hospitality, offline retail, shopping centers, transportation of people and goods. Businesses that are developing due to market dynamics and interaction adjustments using online application platforms such as telecommunications business, online shopping (basic needs and health products), pharmaceuticals, health products, including MSMEs that have switched innovatively to produce health products needed in the Covid-19 pandemic.
\end{abstract}

Keywords: Covid-19, Business, Online Platform.

\section{ABSTRAK}

Penelitian ini bertujuan menemukenali dan menganalisis dampak pandemic Covid-19 terhadap kegiatan Bisnis berbasis platform online di Jakarta. Metode penelitian yang digunakan adalah metode kualitatif deskriptif, menggunakan sumber data sekunder dari hasil riset, referensi dan pemberitaan online yang terkait dengan penelitian. Waktu penelitian Januari sampai pertengahan April 2020. Teknik pengumpulan data menggunakan teknik dokumentasi. Ditemukan bahwa dampak pandemic Covid-19, terkluster pada 3 keaadaan aktivitas bisnis, pertama bisnis bertahan atau stabil, kedua bisnis yang menurun dan ketiga bisnis berkembang. Bisnis yang stabil melalui penyesuaian model interaksi menggunakan platform aplikasi online adalah pendidikan, terutama untuk hantaran makan/minuman 
dan kebutuhan pokok, dan produk kesehatan. Bisnis yang menurun adalah yang berbasis kunjungan atau keberadaan konsumen di tempat sangat terdampak dari pandemi Covid-19, seperti angkutan umum, pariwisata, perhotelan, ritel offline, pusat perbelanjaan, angkutan orang dan barang. Bisnis yang berkembang karena dinamika pasar dan penyesuaian interaksi menggunakan platform aplikasi online seperti bisnis telekomunikasi, belanja online (kebutuhan pokok dan produk kesehatan), farmasi, produk kesehatan, termasuk UMKM yang beralih secara inovatif memproduksi produk kesehatan yang dibutuhkan dimasa pandemi Covid-19.

Kata kunci: Covid-19, Bisnis, Platform online.

\section{PENDAHULUAN}

Pandemi Corona Virus Disease 2019 (COVID-19) diumumkan WHO (World Health Organization) tanggal 11 Maret 2020. Kejadian Covid-19 yang dilaporkan kepada publik pertama kali tanggal 31 Januari 2020 di Wuhan, Propinsi Hubei, RRC. Memasuki Minggu ketiga April 2020 terdapat 170.000 lebih korban yang meninggal, yang sembuh sebanyak 640.000 dari total yang terkonfirmasi positif sebanyak lebih dari 1,4 juta orang (www.corona.help.com, April 2020). Alok Bhargavaa dan kawan-kawan (2001) menemukan bahwa angka kelangsungan hidup yang tinggi akan memberikan kontribusi positif bagi pertumbuhan ekonomi. Di sisi lain Covid-19 telah mengakibatkan angka kematian (mortality) yang tinggi.

Covid-19 telah menimbulkan economic shock, yang mempengaruhi ekonomi secara perorangan, rumah tangga, perusahaan mikro, kecil, menengah maupun besar, bahkan mempengaruhi ekonomi negara dengan skala cakupan dari lokal, nasional, dan bahkan global.

Pada awal kebijakan lockdown kota Wuhan dan pembatasan akses wilayah lainnya di RRC, berdampak pada berkurangnya perayaan Imlek di Tiongkok, karena penutupan akses transportasi dan kegiatan bisnis yang berdampak pada supply chain aktivitas bisnis pabrikan, perdagangan dan bahkan jasa di wilayah terdampak dan wilayah sekitar. Pada awal penyebarannya, Indeks pasar modal bisa menjadi cerminan merosotnya aktivitas ekonomi di Tiongkok. Teguh Santoso (2020) menjelaskan bahwa bursa saham Shanghai Index, TWSE, dan Hangseng menunjukkan nilai negatif dengan indeks yang menurun masing-masing sebesar minus $7.72 \%$, minus $5,72 \%$, dan minus $2,82 \%$. Merosotnya indeks bursa saham Tiongkok tersebut lebih rendah dibandingkan pada saat serangan virus SARS pada 2003, yang mana Shanghai Index dan Hangseng merosot sebesar $-3,4 \%$ dan $-2,58 \%$. Potensi dampak penyebaran virus corona terhadap industri perbankan pada pertumbuhan kredit, pendapatan non bunga dan non bunga bank-bank di kawasan Asia Tenggara diperkirakan bakal melambat

Efek lanjutan berupa melambatnya produksi dan konsumsi di RRC sebagai negara dengan ekonomi terbesar kedua di dunia, turut mempengaruhi supply chain dan perdagangan di belahan dunia lain terutama yang bermitra dalam aktivitas ekspor impor dan bisnis lainnya. Penyebaran covid-19 telah mencapai 189 negara sekaligus menjadi pandemi semakin menimbulkan masalah secara global baik secara politik, sosial, maupun ekonomi. Terlepas dari polemic Covid-19 
sebagai perang biologi atau tidak, Covid-19 telah menghadirkan rasa kekuatiran ketakutan dan menjadi teror bagi masyarakat global, dimana ada yang menyikapi dengan beragam kebijakan di masing-masing negara. Korban manusia serta efek sosial ekonomi secara global oleh pandemic Covid-19, bahkan mampu menggeser pemberitaan mengenai isu perang dan isu terorisme. Terorisme sebelumnya telah mempengaruhi ekonomi dan politik global (Taufik dan Prasilowati, 2019). Covid-19 telah mengganggu ekonomi RRC, bahkan menyulitkan pembuat kebijakan untuk merumuskan kebijakan makro ekonomi (Warwick McKibbin dan Roshen Fernando, 2020).

Indonesia diumumkan terdampak virus oleh Presiden Joko Widodo tanggal 2 Maret 2020, sekaligus menyebutnya sebagai bencana (disaster). Badan Nasional Penanggulangan Bencana (BNPB) secara khusus menyebut Covid-19 sebagai bencana non alam (non natural disaster) dengan skala cakupan nasional. Dibandingkan dengan kejadian pada tahun 2003, ketika kasus SARS terjadi berdampak pada melambatnya perekonomian Indonesia hingga 0,03 persen. Covid-19 yang reproduksi sebarannya lebih cepat dari SARS (Liu, dan kawan kawan: 2020) dan korban meninggal yang lebih tinggi dari SARS dan MERS (Wu dan McCoogen, 2020).

Kementerian Perdagangan menyebutkan adanya dampak Covid-19 untuk pasar ekspor ke RRC, terganggunya rantai pasokan, langkanya bahan baku industri dan produk kesehatan (Kemendag, 2020). Antisipasi dampak dari covid-19 tersebut mendapatkan atensi kebijakan Pemerintah pusat dan Pemda DKI Jakarta yang merupakan episentrum Covid-19, dengan dinamika konsekuensi logis pada kegiatan bisnis.
Penelitian Warwick McKibbin dan Roshen Fernando (2020) menunjukkan bahwa wabah Covid-19 dapat secara signifikan berdampak pada ekonomi global dalam jangka pendek. Skenario tersebut menunjukkan skala biaya yang mungkin dapat dihindari dengan investasi yang lebih besar dalam sistem kesehatan masyarakat di semua negara khususnya di negara-negara yang kurang berkembang dan yang populasi penduduk tinggi.

DKI Jakarta yang merupakan ibu kota negara sekaligus pusat perputaran bisnis di Indonesia, yang dinyatakan sebagai epicentrum Covid-19 di Indonesia, telah menerapkan kebijakan social distances, work from home (WFH) dan pembatasan social berskala besar (PSBB) bagi para aparat pemerintahan daerah, perusahaan, sektor pendidikan dan pengurangan intensitas transportasi public dengan beberapa pengecualian. Terdapat 3.290 perusahaan yang memberlakukan kebijakan WFH di Jakarta (Disnakertrans DKI Jakarta, 6 April 2020). Kebijakan tersebut merupakan upaya mengurangi sebaran Covid-19, yang jika tidak terkendali akan memberikan efek negatif yang lebih besar dan berkepanjangan. Pada aspek bisnis, Jakarta sebagai wilayah episentrum Covid-19 melalui respon guna mengurangi sebaran covid-19 secara kuantitas dinilai dapat berdampak pada aktivitas bisnis. Kehadiran dan penyebaran pandemic Covid-19 yang keberadaannya berada di lingkungan eksternal (external environment) dan tidak terkontrol (uncontrollable) atau diluar kendali perusahaan, maka keberadaanya dinilai berkontribusi menentukan survive tidaknya entitas bisnis dalam aktivitasnya pada berbagai industri di DKI Jakarta. 


\section{TUJUAN PENELITIAN}

Penelitian ini bertujuan menemukan dan menganalisis kegiatan bisnis apa saja yang menurun, stabil atau bahkan meningkat pada saat pandemi Covid-19 serta keberadaan pebisnis yang berbasis penggunaan platform online pada berbagai industri di DKI Jakarta.

\section{TELAAH LITERATUR DAN}

\section{PENGEMBANGAN HIPOTESIS}

\section{Skala Cakupan Sebaran Covid-19}

Elisa M. Maffioli (2020) menjelaskan bahwa tingkat kecepatan dan ukuran skala cakupan penyebaran virus Covid-19 melebihi kasus wabah virus pada kejadian dekade sebelumnya. Covid-19 menyebabkan respon masyarakat dunia sangat berbeda dengan kasus wabah virus yang pernah terjadi sebelumnya seperti virus H1N1 pada tahun 2009-2010, Virus Ebola tahun 2014 di Afrika Barat, atau Virus Zika Amerika Latin tahun 2015-2016, . Hal lain yang membedakan adalah status China yang menjadi titik awal sebaran Covid-19, merupakan Negara dengan kekuatan ekonomi nomor dua dunia sehingga berdampak luas pada interaksi bisnis dengan banyak negara mitra.

\section{Dampak Ekonomi Covid-19}

Naushad Khan dan Shah Faisal (2020) yang meneliti dampak Covid-19 terhadap perekonomian China melalui kajian pada 15 artikel pada berbagai jurnal dan laporan yang membahas kajian pada tema yang terkait. Temuan dalam penetian tersebut bahwa akibat Covid-19 yang diikuti kebijakan lockdown Kota Wuhan dan diikuti karantina kota dan Propinsi lainnya, telah mengurangi dan bahkan menghentikan beragam aktivitas masyarakat, pelajar, mahasiswa, pekerja di area publik, berhentinya pabrikasi, transportasi darat, jalur penerbangan dan ditundanya banyak pembangunan dan tertunda investasi, juga aktivitas sector keuangan, perbankan serta ekspor impor menyebabkan terjadi penurunan angka pertumbuhan (decline) $2 \%$ dari posisi $6 \%$ pada capaian sebelum pandemi Covid-19.

Baldwin dan Tomiura (2020) menemukan kecenderungan bahwa pandemi Covid-19 Pada awal kejadian lock down kota Wuhan dengan beragam kejadian yang diberitakan, telah berdampak negatif pada pemberitaan daninteraksi bisnis bagi warga dan jaringan kota Wuhan Propinsi Hubei, China dan juga ketika virus meluas ke seluruh daratan Tiongkok.

Lebih lanjut Baldwin dan Mauro (2020) menyatakan pada perkembangan Covid-19 selanjutnya, tidak hanya memberikan efek negatif bagi wilayah dan negara yang tertimpa Covid-19, tetapi berdampak lebih lanjut pada negara lain karena terkait dengan value chain economic. Ketika virus meluas keluar dari daratan Tiongkok (Mainland China), maka efeknya pun semakin meluas. Apalagi ketika negara yang menjadi korban terus bertambah terutama Negara Negara memiliki kekuatan ekonomi seperti China, USA, Jerman, Italia, Jepang dan Korea Selatan.

Himanshu Koshle, dkk (2020) yang meneliti dampak Corona virus terhadap bisnis di India, menemukan bahwa pada sektor perdagangan menyebabkan kerugian tidak kurang dari USD 348 juta karena perlambatan perekonomian dan konsekuensi kebijakan.

\section{Inovasi Bisnis Platform Online}

Kontraksi dan perlambatan
perekonomian salah satunya dari
menurunya volume transaksi beragam
bisnis. Terdapat beberapa jenis bisnis yang
relatif bertahan dan mampu tumbuh dalam
kondisi pandemic covid-19 seperti UMKM


yang mengalihkan produksi ke produk kesehatan seperti masker dan hand sanitizer, hal tersebut dinilai sejalan dengan upaya meraih keunggulan bersaing melalui inovasi produk dan orientasi dinamika kebutuhan dan keinginan pasar (Taufik Alwi, Esti Handayani, 2018). Beragam inovasi bisa diterapkan pada berbagai bentuk interaksi bisnis. Interaksi di dunia bisnis dapat berbentuk model B2B (Business to Business) dimana terjadi transaksi bisnis antara pelaku bisnis dengan pelaku bisnis lainnya, B2C (Business to Consumer) bisnis yang dilakukan produsen kepada konsumen secara langsung, C2C (Consumer to Consumer) interaksi bisnis yang dilakukan oleh individu (konsumen) kepada individu (konsumen) lainnya, C2B (Consumer to Business) merupakan model bisnis dimana konsumen (individu) menciptakan dan membentuk nilai akan proses bisnis, B2G (Busines to Government) proses ini terjadi antara pelaku bisnis dan instansi pemerintah, G2C (Government to Consumer) merupakan interaksi antara pemerintah dengan masyarakat sebagai konsumen (Richard Sandhusen, 2008).

\section{METODE PENELITIAN}

Metode penelitian yang digunakan adalah metode kualitatif deskriptif berbasis data sekunder dari hasil riset dan referensi kepustakaan mengenai data dan informasi yang terkait dengan penelitian. Interval waktu kajian kasus pada bulan Januari sampai pertengahan April 2020. Penelitian Entitas bisnis dibatasi di DKI Jakarta.

Teknik pengumpulan data menggunakan teknik dokumentasi sebagai suatu cara yang dilakukan peneliti untuk mengumpulkan data dari berbagai sumber referensi.
Jenis data berupa data sekunder baik berupa data kualitatif maupun kuantitatif dari jurnal dan pemberitaan online. Data sekunder adalah data yang mengacu pada informasi yang dikumpulkan dari sumber yang telah ada. Sumber data sekunder adalah catatan atau dokumentasi perusahaan, dokumentasi pemerintah atau publikasi pemerintah, analisis industri oleh media, situs web dan lainnya (Uma Sekaran, 2011).

\section{HASIL PENELITIAN DAN PEMBAHASAN Hasil Penelitian}

Data yang dirilis oleh website corona. help.com dan website worddometer.com per 3 April 2020, menunjukkan bahwa Indonesia berada pada urutan pertama diantara negara-negara ASEAN, berdasarkan dari total angka akumulasi kematian akibat Covid-19 dengan Jakarta sebagai epicentrum penyebaran Covid-19 di Indonesia. Data Covid-19 di DKI Jakarta akumulasi Orang dalam Pemantauan (ODP) dan Pasien Dalam Pengawasan (PDP) dari tanggal 11 Maret sampai 25 Maret 2020 berjumlah 1617 orang (https://corona.jakarta.go.id/id/data, diakses 25 maret 2020).

Kebijakan dan upaya pencegahan skala sebaran Covid-19 yang pertama kali diumumkan oleh Presiden Joko Widodo, 2 Maret 2020, telah berimbas pada perubahan cara dan ritme beragam aktivitas, baik sosial kemasyarakatn, pelayanan public maupun kegiatan bisnis. Status Jakarta sebagai epicentrum Corona direspon oleh Pemda DKI melalui Instruksi Gubernur DKI Jakarta Nomor 16 Tahun 2020, tentang peningkatan kewaspadaan terhadap risiko penularan infeksi Covid19. Aplikasi kebijakan baik yang merupakan turunan dari kebijakan pemerintah pusat maupun kebijakan 
Pemda DKI yang terkait dengan aktivitas bisnis dan masyarakat seperti:

1) Penutupan awal 17 tempat Wisata yang dikelola Pemda DKI

2) Penutupan tempat-tempat rekreasi yang dikelola Swasta

3) Penutupan pusat perbelanjaan Mall

4) Pembatasan jam buka pasar tradisional

5) Pembatasan jumlah armada dan intensitas waktu operasi transjakarta

6) Seruan bekerja dari rumah bagi karyawan aktivitas perusahaan dan bisnis

7) Belajar dari rumah untuk kegiatan sekolah dasar, menegah dan tinggi

\section{Implikasi dari Kebijakan Pemerintah}

Seruan dan kebijakan Pemerintah daerah DKI Jakarta, secara bertahap mempengaruhi ritme dan rutinitas yang berlangsung seperti biasanya. Sentra sentra perbelanjaan menurunkan aktivitasnya, destinasi wisata meliburkan layanannya seperti TMII, Dufan, Ancol, Museum, Kota Tua, Monas, TIM, Ragunan. Pengumunan resmi baik penutupan pusat perbelanjaan dan tempat wisata, disertai dengan sebaran informasi di media massa. Penyebaran informasi melalui WOM (word of mouth) baik melalui penyampaian lisan, media konvensional maupun sosial media dalam interaksi antar konsumen di masyarakat semakin meningkatkan kuantitas dan cakupan sebaran informasi.

\section{Pembahasan}

Covid-19 sebagai salah satu kejadian yang keberadaannya berada di lingkungan eksternal (external environment) relatif tidak terkontrol (uncontrollable) atau diluar kendali perusahaan. Berdasarkan data sekunder yang diperoleh dalam kurun waktu penelitian terlihat bahwa Covid 19 berdampak pada lingkungan internal (internal environment) entitas bisnis. Covid 19 berdampak pada pola kebiasaan aktivitas bisnis secara konvensional dalam bidang pemasaran, keuangan, sumber daya manusia dan operasional. Sebagian perusahaan yang memperhatikan trend pasar dan inovasi produk berupaya menyesuaikan dengan aplikasi online.

\section{Eksistensi Bisnis dari Vendor Berbasis Platform Aplikasi}

Pencegahan penyebaran pandemi Covid-19, yang disertai dengan kebijakan Pemerintah Daerah DKI Jakarta yang memberlakukan work from home (WFH), social distance dan physical distance serta penerapan pembatasan sosial berskala besar (PSBB) berdasarkan data yang ada menunjukkan adanya pengurangan beberapa aktivitas bisnis seperti pada pusat-pusat perdagangan, kegiatan perdangangan sektor mikro, kecil dan menengah (UMKM), kegiatan pendidikan, pariwisata, perhotelan, transportasi dan beragam aktivitas bisnis lainnya,

Berdasarkan kasus yang terjadi di DKI Jakarta, terdapat beberapa bidang kegiatan yang terdampak oleh pandemic covid-19, sebagai berikut.

1) Pendidikan Dasar, Menengah dan Tinggi

Pada bidang pendidikan dasar, menengah dan tinggi baik yang negeri maupun swasta, terdampak Covid-19, bahkan Kementerian Pendidikan dan Kebudayaan mengeluarkan kebijakan belajar dari rumah (learn from home) untuk seluruh level pendidikan. Kebijakan tersebut, sebagai solusi pencegahan penyebaran, walau pun konsekuensinya terjadi perubahan media dan cara pembelajaran. Kondisi tersebut menuntut kemampuan penyesuaian dari tenga pendidik, tenaga non kependidikan, peserta 
didik, media dan teknologi pendukungnya.

Gambar 1

Interaksi Jasa Pendidikan

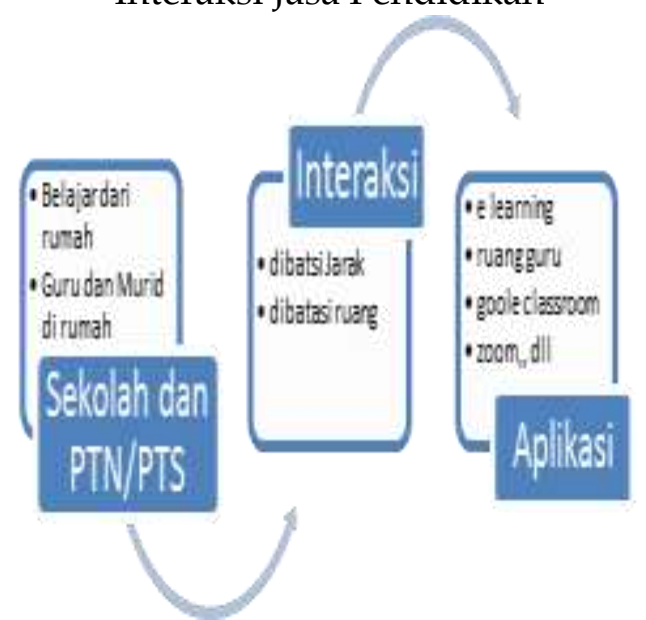

Sumber: Diolah peneliti, 2020

Pada kondisi tersebut aktivitas di bidang pendidikan tetap bisa berjalan secara daring melalui pengunaan aplikasi vendor penyedia layanan daring dengan menggunakan media belajar daring. serta menjadi trend dan digunakan oleh peserta didik, guru/dosen serta lembaga pendidikan. Beberapa aplikasi platform video conference yang memungkinkan interaksi guru/dosen dengan peserta didik seperti elearning Edmodo, Google Suite for Education berupa Google Class Room atau Google Meet, Kelas Pintar, Microsoft Office 365 for Education, Quipper School, Ruangguru, Sekolahmu, Skype, UmeetMe, WebEx, Webinar, Zenius, Zoom, menjadi alternatif aplikasi yang digunakan.

Berdasarkan

website

Kemendikbud RI, terdapat 12 aplikasi yang bisa digunakan oleh siswa dan guru yang bekerjasama dengan Kemendikbud menyediakan aplikasi pembelajaran daring (online) untuk siswa dan guru di seluruh Indonesia yaitu: Cisco Webex, Google for
Education, Icando, IndonesiaX, Kelas Pintar, Meja Kita, Microsoft Office 365, Ruangguru, Rumah Belajar, Sekolahmu, Quipper School, dan Zenius.

Zaharah, Kirilova dan Windarti (2020) menambahkan bahwa kebijakan bekerja dari rumah yang diserukan pemerintah diharpkan meminimalisir sebatan virus dengan tetap menjalankan aktivitas pendidikan melalui beragam aplikasi online.

2) Perdagangan

Konsekuensi dari himbauan penutupan pusat perbelanjaan dan social distance adalah berkurangnya jumlah toko atau outlet yang dibuka, jam buka took/outlet serta jumlah konsumen yang berkunjung. Hal ini berdampak pada tiga sisi, yaitu pertama bagi pelaku usaha perdagangan (termasuk usaha mikro dan kecil), kedua, konsumen, dan ketiga pemilik property seperti pemilik pertokoan/mall/plaza.

\section{Gambar 2}

Interaksi Perdagangan
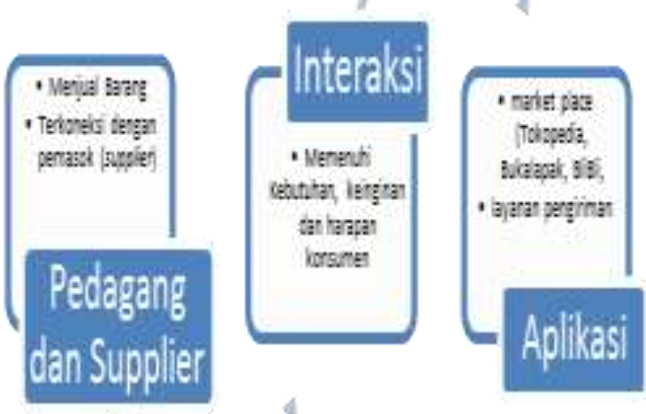

Sumber: Diolah peneliti, 2020

Pada bisnis perdagangan (commerce) trend penggunaan $\mathrm{E}-$ commerce oleh pelaku usaha dan interaksinya dengan pemasok (supplier) menemukan momentum 
yang lebih siap bagi pelaku usaha yang sudah eksis lebih awal dalam penggunaan marketplace dan momentum baru bagi pebisnis yang baru memulai menggunakan ecommerce. Pada kasus pedagang mikro seperti pedagang yang membuka warung pedagang kaki lima dan pedagang keliling (penjual jamu, sayuran, makanan, minuman) di saat kekuatiran terhadap Covid-19 meningkat akan terdampak pada kunjungan dan pesanan dari konsumen.

Di sisi konsumen, trend belanja online (online shopping) meningkat disertai dengan penggunan beragam pilihan aplikasi yang ditawarkan oleh vendor platform marketplace dan situs belanja. Beberapa marketplace seperti: Bukalapak, BliBli, Lazada, Shopee, Tokopedia, dsb.

Saat Pemda DKI Jakarta memberlakukan kebijakan bekerja dan belajar dari rumah, salah satu platform belanja online Ralali.com yang memediasi antara produsen, penjual dan pembeli terutama merespon dukungan di pasar yang dikelola PD Pasar Jaya dan pasar tradisional lainnya di wilayah DKI Jaya

Bagi pemilik property pusat perbelanjaan, kendala utama dari dampak jumlah penjual (merchant) sebagai penyewa ruangan/space yang berkurang termasuk penyewaan ruangan untuk eksebisi di pusat perbelanjaan.

3) Angkutan online

Angkutan umum sangat terdampak pada penurunan jumlah penumpang. Di satu sisi penurunan jumlah armada dan intensitas layanan TransJakarta dan angkutan publik di Jakarta, untuk mendukung kampanye dirumah saja menyebabkan berkurangnya jumlah warga yang lalu lalang di Jakarta.

Gambar 3

Interaksi Angkutan Online

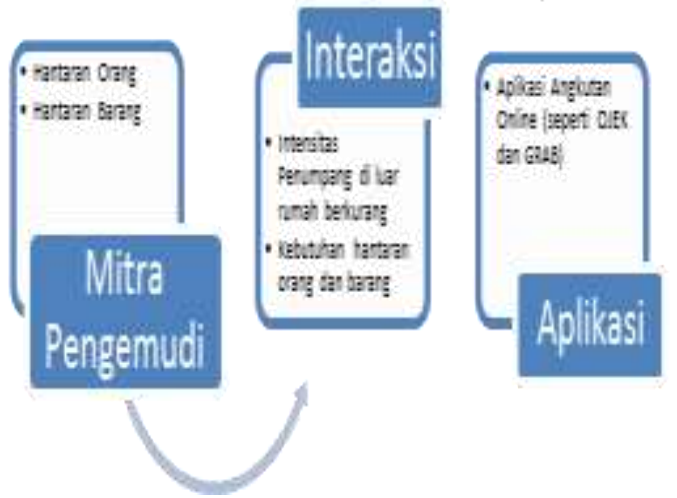

Sumber: Diolah peneliti, 2020

Untuk angkutan online pun terasa dampaknya karena pengurangan aktivitas warga di luar rumah. Mitra pengemudi online mengeluhkan menurunnya jumlah penumpang. Hal tersebut akan mengurangi pendapatan mitra pengemudi. Namun dalam kondisi pandemi Grab dan Gojek tetap memberikan solusi kemitraan. Hal tersebut penting untuk menjaga loyalitas mitra (Taufik Alwi: 2018) dan menjaga kemitraan tersebut ketika wabah berakhir. Sementara itu, berbagai kebutuhan masyarakat yang berada di rumah membutuhkan solusi untuk mengakses dan memperoleh barang yang dibutuhkan. Kondisi tersebut menjadi momentum penguat kehadiran aplikasi angkutan online yang saat ini didominasi oleh Gojek dan Grab. Fahmi Ahmad Burhan (2020) menjelaskan bagi kedua perusahaan berbasis platform online tersebut masing-masing menjalin kerjasama dengan penjual (merchant) kondisi pandemic Covid-19, masih memberikan peluang terutama untuk layanan pesan antar 
makanan/minuman, dan bahan pokok serta produk kesehatan.

4) Perhotelan

Pada bisnis perhotelan yang menyediakan akomodasi penginapan dan juga ruangan (Seminar, pernikahan, dll) mengalami penurunan pemesanan secara drastis, karena penginap yang awalnya banyak dari wisatawan mancanegara maupun domestik semakin berkurang karena kekuatiran pandemi yang menyebar sehingga mengurangi perjalanan dan kebutuhan menginap di hotel.

Gambar 4

Interaksi Bisnis Perhotelan

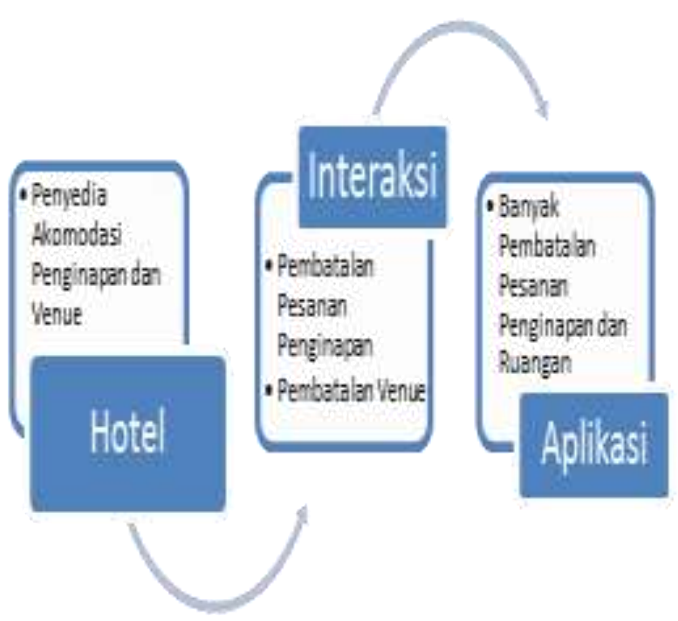

Sumber: Diolah peneliti, 2020

Walau pun menggunakan aplikasi pemesanan online, tetapi karena hotel berbasis pada tempat yang didatangi, maka berkurangnya perjalanan dan kunjungan menyebabkan bisnis perhotelan turun signifikan dibandingkan sebelum masa pandemi covid-19. Disampin itu platform online pemesanan hotel banyak yang mendapat rescheduling bahkan pembatalan dari konsumen.
5) Pariwisata

Penutupan tempat wisata di Jakarta sejak 14 maret 2020 yaitu Monas, Kota Tua. Ancol, Dunia Fantasi Atlantis Water Adventures, Ocean Dream Samudra, Sea World, Allianz Ecopark, Taman Margasatwa Ragunan, TMII, Setu Babakan, Planetarium Taman Ismail Marzuki, Rumah si Pitung, Taman Arkeologi Onrust, Museum-Museum (Bahari, Sejarah Jakarta, Prasasti, MH Thamrin, Seni Rupa dan Keramik, Tekstil, Wayang, Joang 45, MACAN, Mandiri, Maritim Indonesia, Sumpah Pemuda, Kebangkitan Nasional, Bank Indonesia) dan Perpustakaan Nasional (website travelkompas.com, diakses 24 Maret 2020) otomatis sementara menghilangkan aktivitas layanan dan kunjungan dari wisatawan.

Hal tersebut juga terkait dengan beragam aktivitas pendukung dan kegiatan usaha mikro dan kecil yang bisanya melayani warga yang berkunjung di tempat atau destinasi wisata.

\section{Gambar 5}

Interaksi Bisnis Pariwisata

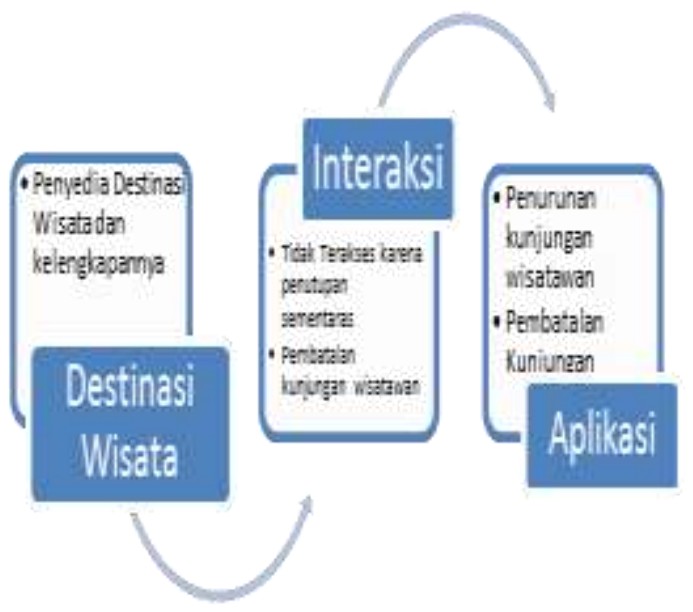

Sumber: Diolah peneliti, 2020 
6) Farmasi dan Produk Kesehatan

Kebutuhan masyarakat dan pemerintah atas tersedianya obatobatan dan produk kesehatan mendorong peningkatan produksi dan permintaan. UMKM yang inovatif bahkan bisa menyesuaikan diri dengan beralih memproduksi alat kesehatan yang dibutuhkan. Gambar 6

Interaksi Bisnis Farmasi dan Produk Kesehatan

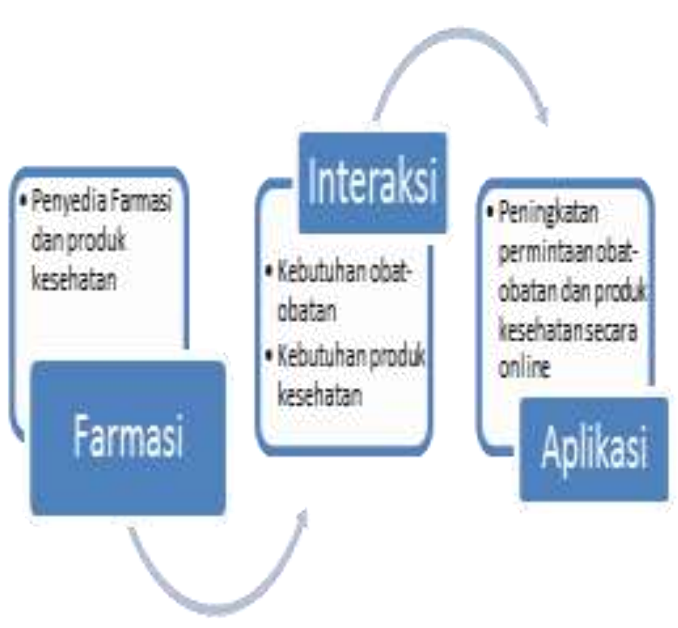

Sumber: Diolah peneliti, 2020

\section{KESIMPULAN}

1. Kejadian Pandemi Covid-19 yang merupakan bencana non alam (non nature disaster) menjadi salah satu faktor dari lingkungan luar (external environment) yang memberikan dampak penurunan aktivitas bisnis konvensional (offline), namun bisa mengungkit kegiatan bisnis yang inovatif berbasis platform online.

2. Bidang usaha yang terkendala perkembangannya bahkan mengalami penurunan selama masa pandemic Covid-19 adalah bisnis transportasi umum, Pariwisata, Perhotelan, pusat perbelanjaan, serta pedagangan offline yang hanya fokus pada kunjungan langsung konsumen.
3. Kegiatan bisnis yang masih bisa bertahan dan eksis melayani konsumen (melalui penyesuaian model interaksi layanan menggunakan platform aplikasi online) adalah pendidikan, ritel bahan kebutuhan pokok, bisnis pengiriman barang online terutama untuk hantaran makan/minuman dan kebutuhan pokok.

4. Kegiatan bisnis yang berkembang pada masa pandemic adalah telekomunikasi, penyedia/vendor platform online, farmasi, produk kesehatan melalui penyesuaian platform bisnis berbasis online.

\section{SARAN}

1. Bagi pengusaha UMKM, terutama usaha mikro dan kecil perlu memanfaatkan momentum Covid-19 sebagai langkah menyesuaikan diri secara cepat dengan mengembangkan inovasi produk sesuai dengan kecenderungan permintaan pasar disertai penyesuaian e-commerce dan aplikasi online.

2. Keterbatasan penelitian ini yang hanya menggunakan data sekunder perlu diteliti lebih lanjut dengan desain penelitian dan cakupan penelitian yang lebih lengkap.

\section{DAFTAR PUSTAKA}

Alwi, T., Handayani, E., 2018, "Keunggulan Bersaing UKM yang dipengaruhi oleh Orientasi Pasar dan Inovasi Produk", Jurnal Pengembangan Wiraswasta, Vol 20, No. 3, 193-202, LP2M Sekolah Tinggi llmu Ekonomi IPWI Jakarta, DOI: http://dx.doi.org/10.33370/jpw.v20i3. 256

Alwi, T., 2018, "Pengaruh Kepercayaan Mitra dan Komitmen Perusahaan terhadap Loyalitas Mitra Pengemudi 
Ojek Online". Jurnal Manajemen Kewirausahaan, Vol. 14, No. 2: 223232, LP2M Sekolah Tinggi IImu Ekonomi IPWI Jakarta. DOI: http://dx.doi.org/10.33370/jmk.v14i2. 95

Baldwin, R., Mauro, B. W., 2020, Economics in the Time of COVID-19, CEPR Press VoxEU. org.

Baldwin, R., Tomiura, E. 2020, Thinking ahead about the trade impact of COVID-19, CEPR Press VoxEU. Org

Bhargavaa, A., Dean T. Jamisonb, Lawrence J. Lauc, Christopher J.L. Murray, 2020, "Modeling the effects of health on economic growth", Journal of Health Economics. 20, 423440

Elisa M. Maffioli, 2020, How is the World Responding to the 2019 Coronavirus Disease Compared with the 2014 West African Ebola Epidemic? The Importance of China as a Player in the Global Economy, Am. J. Trop. Med. Hyg., $00(0), \quad$ pp. 1-2 doi:10.4269/ajtmh.20-0135

Fahmi Ahmad Burhan, 2020, Beda Cara Gojek dan Grab Tekan Dampak Pandemi Corona terhadap Mitra, https://katadata.co.id/berita/2020/0 4/01/beda-cara-gojek-dan-grabtekan-dampak-pandemi-coronaterhadap-mitra, diakses 5 April 2020, pukul 13.10

https://travel.kompas.com/read/2020/03/1 6/210300127/update-daftar-30tempat-wisata-di-jakarta-yangtutup-untuk-cegah-penyebaran. Diakses 22 Maret 2020, pukul 10.15. https://travel.kompas.com/read/2020/03/1 6/210300127/update-daftar-30tempat-wisata-di-jakarta-yangtutup-untuk-cegah-penyebaran. Diakses 24 Maret 2020.

https://www.kemendag.go.id/id/newsroo $\mathrm{m} /$ press-release/dampakperdagangan-global-melambatdan-mewabahnya-covid-19mendag-ajak-kadin-dan-akademisiperkuat-ekspor-dan-perdagangandalam-negeri-1, diakses 20 Maret 2020, pukul 13.10.
Khan, N., Faisal, S. 2020, Epidemiology of Corona Virus in the World And Its Effects on The China Economy, Electronic copy available at: https://ssrn.com/abstract=3548292, diakses 26 maret 2020

Koshle, H., Kaur, R. Basista. R, 2020, Breakdown of Business and Workers in India, Impact of Corona Virus, March 19, available at http://dx.doi.org/10.2139/ssrn.355754 4. diakses 25 Maret 2020

McKibbin , W., Fernando R., 2020, The Global Macroeconomic Impacts of COVID-19: Seven Scenarios, CAMA Centre for Applied Macroeconomic Analysis, 29 February 2020, P. 1-43, Australian National University, ISSN 2206-0332

Sandhusen, R. 2008. Marketing. Hauppauge, N.Y: Barron's Educational Series Inc., U.S..

Sekaran, Uma. 2011. Research Methods For Business (Metode Penelitian Untuk Bisnis). Jakarta: Salemba Empat.

Taufik, Prasilowati, S., L., 2019, "Terror Management, Economic Growth and Islamic Perspective toward the World Peace", Proceedings 3rd Indonesia International Defence Science Seminar 2019, Volume 5, Pages 74-82, ISBN 978-602-5808-52-4, Indonesia Defense University. http://www.iidss.org/proceeding/

Teguh Santoso, Mitigasi Dampak Ekonomi Virus Corona, Diambil dari https://news.detik.com/kolom/d4913486/mitigasi-dampak-ekonomivirus-corona, diakses 27 Februari 2020, pukul 09.34

Ying Liu, Albert A. Gayle, Annelies WilderSmith and Joacim Rocklöv, 2020. "The reproductive number of COVID19 is higher compared to SARS coronavirus". Journal of Travel Medicine, 1-4, doi: 10.1093/jtm/taaa021

Zaharah Z, Galia Ildusovna Kirilova, Anissa Windarti, 2020. Impact of Corona Virus Outbreak Towards Teaching and Learning Activities in Indonesia, 
Jurnal SALAM. Vol 7, No 3 P-ISSN: 23561459 E-ISSN: 2654-9050.

Zunyou Wu, Jennifer M. McGoogan, 2020,

"Characteristics of and Important Lessons From the Coronavirus Disease 2019 (COVID-19) Outbreak in China",
Journal American Medical Association, JAMA, February 24, 1-4 